\title{
Il y a 200 ans à Versailles
}

\author{
Bermard Coppens
}

\section{Mai 1789}

Ence 21 mai, fête de l'Ascension, les députés du Clergé, de la $\mathcal{N}$ oblesse ơdu'Tiers-Etat, qui sont réunis d Versailles pour y tenir les Etats Généraux du Royaume, ont suspendu les séances de leurs chambres respectives. Qu'ils se rassemblent par petits groupes, selon leur province d'origine ou selon leurs affinités, ou qu'ils se retirent dans leur logement pour écrive à leurs commettants, tous mettent d profit ce jour de relâche pour faire le point de la situation.

Depuis l'ouverture solennelle faite par le Roile 5 mai, les Etats Généraux n'ont pas encore pu se constituer, ni entamer leurs travaux dont toute la France attend pourtant la solution des problèmes accumulés depuis tant de générations, problemes dont la manifestation la plus douloureuse est l'insoutenable déficit des finances publiques.

Mais pour que les Etats Généraux puissent se constituer, if faut au préalable que les députés se soumettent a la vérification de la validité de leur élection. Or, la Noblesse prétend que cette opération doit se faire d l'intérieur de chaque ordre, alors que le Tiers-Etat téclame La vérification en commun des pouvoirs, s'appuyant sur le fait que les députés sont appelés d̀ travailler en commun.

La $\mathcal{N o b l e s s e ~ L l e ~ T i e r s - E t a t ~ n e ~ v e u l e n t ~ p a s ~ s e ~ d e ́ p a r t i r ~ d e ~}$ leur position, parce que la solution de cette question préalable emportera avec elle la solution du probleme de fond: les décisions seront-elles prises dans les Etats Généraux en votant par ordre, ou en votant par tête? Dans la première Fypothèse, les jeux seraient faits d'avance puisque Clergé Noblesse -Les deux ordres privilégiés-uniront leur voix contre la seule voix du Tiers, ce qui provoquerait une immense déception dans le pays qui attend de ces Etats Généraux la fin de tous ses maux parla fin des abus qui se sont introduits au cours des siècles dans le corps social. Dans la seconde hypotfièse, les décisions itont immanquablement dans le sens du Tiers-Etat puisque cet ordre a obteru, le 27 décembre 1788, une représentation égale d celle des deux ordres réunis, o qu'il peut comptersurl'appoint des voix de quelques nobles "éclairés", aitusi que sur celles d'une bonne partie du "bas clergé".

\section{May 1789}

May 21, Ascension Day. Representatives of the Clergy, of the Nobifity, and of the Third Estate, gathering in Versailles to hold the Fstates General of the Kingdom, have adjourned the sessions of their respective Houses. Whether they meet in small groups, according to their province of origin, or to their affinities, or whether they retire to their rooms to report to their constituents, all take the opportunity of this holiday to assess the situation.

Since the official opening by the King on May 5th, the Estates General have not yet formed or begun their work on the many problems that have piled up for so many generations. One problem, the deficit of the public treasury, is particularly distressing.

However, in order for the Estates General to form, the validity of the representatives' election first has to be checked. The Nobility claims that this should be done separately within each order, whereas the Third Estate demands a common check of the proxies, arguing that the representatives will have to work in common in the future anyway.

The Nobility and the Third Estate both stand by their positions, because the solution to this prerequisite question will entail the solution to the heart of the problem: will future decisions be made by the Estates General through a vote by order, or by personal votes? In the first case, the game would not be fair since the Clergy and the Nobility, the two privileged orders, would unite their votes against the sole vote of the Third Estate. Clearly, this situation would generate a fuge disappointment in the country, which hopes from these Estates General that all problems will be solved simply by bringing to an end all kinds of social abuses having accumulated over the centuries. In the second case, the decisions would conversely be along the lines of the Third Estate, since that order had succeded to obtain, on December 27 th, 1788, a number of representatives equal to that of 6 oth other orders, and it may count on a few additional votes of a few "enlightened" nobles, and on a significant fraction of those of the lower clergy. 
Mais ceci signifierait la fin des privilèges, donc la transformation complete du royaume, o l'on pense bien que les privilégiés ne sont pas décidés à se laisser dépouiller sans opposer la plus ferme résistance.

Le Roi, qui ne se sent pas capable de faire respecter ses décisions, n'a pas osé trancher lui-même la question du mode de scrutin, et en a laissé la responsabifitéa aux Etats Généraux eux-mêmes. Cette faiblesse de l'autorité royale est la cause de l'inaction del'assemblée, qui ne peut prendre aucune décision tant qu'elle n'est pas constituée, of qui ne peut pas se constituer tant qu'elfe ne peut pas prendre de décision.

Ainsi chaque ordre tient-if une conduite différente, cherchant ḋ dénouer la crise dans le sens de ses revendications.

Le Tiers-Etat s'assemble chaque jour dans la salle des Menus Plaisits, celfe dans laquelle s'est tenue la séance d'ouverture en présence du Roi, prétend ne pouvoir se cons. tituer qu'en présence $\sigma$ avec les deux autres ordres, $\%$ ne se considére en attendant que comme une réunion de citoyens qui attend de se réunir d d'autres citoyens. Les députés s'occupent de questions de procédure ov essayent de trouver une façon d'agir sans se reconnaitre constitués. Leur démarche est toute tracée: inviter les deux autres ordres d se réunird eux, vérifier les pouvoirs en commun $๘$ voter par tête; si la X Xoblesse et le Clergé refusent, Le Tiets est décidé d se proclamer la Nation d faire des lois qui assujettiront également les classes privilégiées.

La Noblesse se réunit de son côté, vérifie ses pouvoirs (6 mai) ơ se déclare chambre constituée (11 mai), affirmant de cette façon qu'elle n'entend en rien entrer dans les vues du Tiers.

Le Clergé, divisé en tre prélats curés, veut jouer un rôle concifiateur entre les deux autres ordres. Aussi a-t-il proposé que les pouvoirs de tous les députés soient vérifiés par les commissaires choisis dans les trois ordres. La Noblesse, qui a rejeté cette proposition, a néanmoins accepté de nommer des commissaires a fin de conférer avec ceux des autres ordres sur des moyens de concifiation. Ses commissaires $\%$ ceuxdu Tiers ont été nommés le 19. Connus pour la plupart pour leur position intransigeante, leur choix ne permet pas d'augurer qu'une concifiation aura lieu, o on n'attend de ces conférences aucun autre résultat que d'aigrir davantage les esprits.
But that would mean the end of the privileges, hence a complete transformation of the Kingdom, and it is a matter of course that those benefiting from them will fight most vigourously to oppose it.

The King, who thinks he is not strong enough to impose fis decisions, fas not dared decide which ballot system should be used, and has left the question to be settled by the Tstates General themselves. This weakness of the royal authority fas Grought the proceedings to a standstill, since the assembly cannot take decisions if it has not formed, and cannot form without having taken a decision.

Therefore, each order follows a different path, trying to overcome the crisis to his own advantage.

The Third Estate gathers everyday in the "Room of the Little Pleasures", the very room in which the opening session fad been feld in the King's presence. It claims that it can form only together with the other two orders, and thinks of itself only as a meeting of citizens waiting for other citizens tojoin them. Its representatives are busy with matters of procedure, and try to find a way to act without being formed. Their plan is straightforward: they want to invite the two other orders to join them, check the proxies in common, and hold personal votes; if the Nobility and the Clergy refuse, then the Third Estate will name itself the Nation, and will make laws to which the privileged classes will also have to be subjected.

The Nobility meets separately, checks its oum proxies (May 6th), and declares itselfformed, thereby demonstrating that it does not in the least support the views of the Third Estate.

The Clergy, divided between preasts and prelates, wants instead to play a conciliatory role between the two other orders. Accordingly, it has proposed that all proxies be checked by commissioners chosen within the three orders. The Nobility has rejected this proposal, 6ut has agreed to name commissioners to discuss with those of the two other orders about possible means of concifiation. Its commissioners and those of the Third Estate have been appointed on the 19th. Mast of them being known for their uncompromising views, their choice in fact Leaves no hope as to a future conciliation, and no result is expected from these meetings otfer than embittering the minds even more. 
Adrien Duquesnoy, députédu Tiers-Etat de Bar-Le-Duc, écrit ce jour d̀ ses commettants: "Quoiqu il arrive, nous ne sortirons de la crise actuelle que par une secousse terrible, ob après nous être longtemps battus les uns contre les autres avec nos fers, nous nous endormirons de lassitude dans le sein du despotisme le plus absolu.".
Adrien Duquesnoy, representative of the Third $\mathcal{E}$ state of Bar-Le-Duc, writes that day to his constituents: 'Whatever happens, we will come out of the present crisis only through a terrible upheaval, and after fiaving fought each other for a long time, we will be so weary that we will sleep into the utmost despotism.'

\begin{tabular}{|c|c|c|c|c|c|}
\hline Heures & $\begin{array}{c}\text { Temper. } \\
{ }^{\circ} \mathrm{R} \cdot{ }^{\circ} \mathrm{C}\end{array}$ & $\begin{array}{c}\text { Press } \\
\text { Pouc.lig. }_{\text {or }}\end{array}$ & Hygrom. & Ciel & Sky \\
\hline $5 \mathscr{A M}$ & $7,8 \cdot 9.8$ & $27.11,7 \cdot 757.3$ & & Couvert. Gouttes d'eau & Cloudy. Some raint \\
\hline Noon & $18,0-22.5$ & $27.11,9 \cdot 757.8$ & 77 & vers 6 hio de Caprès-midi & in the afternoon \\
\hline Midnight & $11,5-14.4$ & $27.11,9-757.8$ & & & \\
\hline
\end{tabular}

(") A 23 toises au-dessus du niveau moyen de la Seine (alt.70 m)

Les députés du Tiers-Etat débattent la motion présentée Le 20 mai par $\mathcal{M}$. de la Borde qui propose la formation d'un comité de rédaction qui rédigerait ce que la chambre jugera d propos de publier. La majorité se déclare contre cette motion, trop hâtive, ơ estime qu'il ne faut pas décréter avant d'être constitué ce qu'il ne convient de décréter qu'après s'être constitué.

La chambre du Clergé se divise en 6ailliages pour travailLer d̀ l'examen de ses cafiers.

Paris. Un des émeutiers artêtés lors des événements du 28 avril au faubourg Saint-Antoine (affaire Réveillon), Pierre Mary, écrivain, est pendu. Cinq autres émeutiers assistent d l'exécution attachés au carcan. ILs sont ensuite marqués au fer rouge conduits auxgalères (c.d.d. au bagne). La femme Bertin, également condamnée d̀ être pendue, $\sigma$ qui s'est déclarée grosse, a obtenu un sursis.

Ce parlement de Paris enregistre une "déclaration duRoi" qui attribue aux prévôts des matéchaussées la connaissance † le jugement en dernier ressort des particuliers prévenus d'émotions populaires, d'attroupements, d'excès of de vioLences, qui ont lieu dans différentes provinces. Cette façon de rendre la justice est particufièrement expéditive.
(*) 138 feet above mean level of river Seine (i.e. $70 \mathrm{~m}$ a.s.l.)

The representatives of the Third'Estate discuss the motion presented by Mr. de la Borde, who suggests the creation of a board of editors to write up what the House will see fit to publish. A majority stands against this hasty motion, and thinks that one cannot decree before the formation takes place what one may decree only afterwards.

The Clergy splits into bailiuvicks to work on their records.

In Paris, one of the rioters arrested during the events of April 28th in Fau6ourg Saint-Antoine (the Réveillon case), Pierre Mary, writer, is hanged. Five other rioters witness the execution tied toiron collars. They are then branded with redfot iron and sent to the galleys. The sentence to also hang a woman Bertin, who declared herself pregnant, is suspended.

The Paris Parfiament records a "Xing's declaration", who gives to provosts of the constabulary the power to judge in last resort individuals involved in popular uprisings, gatferings, excesses and violent acts having taken place in various provinces. This form of justice is particularly expeditious. 
Saturday, May $23^{\text {rd }}, 1789$

\begin{tabular}{|c|c|c|c|c|c|}
\hline Heures & $\begin{array}{c}\mathcal{T}_{\text {emper. }} \\
{ }^{\circ} \mathcal{R} \cdot{ }^{\circ} \mathrm{C}\end{array}$ & $\begin{array}{c}\text { Press. } \\
\text { Pouclig. - Torr }\end{array}$ & Hygrom. & $\mathrm{Ciel}$ & Sky \\
\hline $5 \mathscr{A M}$ & $11,2-14.0$ & $28.0,1-758.2$ & & Assez Geau toute & Rather fair \\
\hline Noon & $19,9 \cdot 24.9$ & $28.0,6-759.4$ & 72 & Ca joumée & the whole day \\
\hline 10 h3 $30 \mathcal{P M}$ & $14,8 \cdot 18.5$ & $27.11,3 \cdot 756.4$ & & Aurore Boréale d 11א & Aurora Borealis at 11PM \\
\hline
\end{tabular}

Versaifles. Chambre du Tuers-Etat (qui affecte de ne se désigner que par la dénomination de "communes").M. Target, s'appuyant sur les afarmes que répandent dans les provinces C'inaction ef he silence que gardent les Etats Généraux, reprend La proposition de former un comité de rédaction. Mais cette motion est une nouvelle fois repoussée d la majorité des suffrages.

La chambre de la Noblesse autorise ses commissaires d annoncer au Tiers Etat que la $\mathcal{N}$ oblesse tenoncera $d$ tous ses priviliges en matière d'impositions dés que chaque ordie, défibérant librement, aura pu établir les principes constitutionnels sur une base solide.

Les 32 commissaires conciliateurs (8 pourle Clergé, 8 pour la Noblesse ef 16 pour le Tiers-Etat) s'assemblent vers 6 h du soir. Mais rien n'est conclu au cours de cette première conférence, of les commissaires s'ajoument au 25.

Un arrêt du Conseil d'Ttat du Roi tenouvelle les défenses de Gâtir sur le terrain des Champs Elysées a Paris, en exécution des déclarations de 1724,1726 et 1728 sur la fixation des limites de Paris.

Paris. Inauguration d la Bourse du buste du Roi exécuté par $\mathcal{M}$. Houdon. Dans son discours, $\mathcal{M}$. Diancourt dit: "Adressons nos vceux d l'Etre suprême pour que le Roi et ce ministre vertueux (MM. N (ecker) soient d jamais inséparables, or qu'ils ne cessent de s'occuper, comme ils le font, de notre repos, de notre bonfieur de de la féficité publique."
Versailles. In the House of the Third Estate, which now pretends to be known only under the name of "Commons", Mr. Target, drawing on the concern spreading in the provinces about the idleness and the silence of the Estates General, proposes once more to appoint a board of editors. But this motion is once more rejected by a majority of votes.

The House of the Nobility allows its commissioners to inform the Third Estate that the Nobility will relinquish all its taxprivileges as soon as each order, in a free deliberation, establishes the contitutional principles on a sound basis.

The thirty-two conciliatory commissioners (eight for the Cletgy, eight for the Nobility, and sixteen for the Third Estate) meet around 6 p.m. But notfing comes out of this first conference, and the meeting is adjourned until the 25th.

A judgment by the Council of State of the King reiterates the interdiction to build on the Champs Elysées grounds, as ruled by the declarations of 1724,1726 , and 1728 on the question of setting the limits of the city of Paris.

Paris. Inauguration at the stock exchange of a bust of the King 6y MTr. Houdon. In fis discourse, MMr. Diancourt says: "Let us send to the Supreme Being our wishes that the King and this virtuous Minister (MMr. O(ecker) never split, and that they continue to look after our rest, after our fappiness, and after the public peace, as they are now doing. "

\section{Dimanche 24 mai 1789.}

Sunday, May 24, 1789

\begin{tabular}{|c|c|c|c|c|c|}
\hline Heures & $\begin{array}{c}\text { Temper. } \\
{ }^{\circ} \mathcal{R} \cdot{ }^{\circ} \mathrm{C}\end{array}$ & $\begin{array}{c}\text { Press. } \\
\text { Pouc.fig. - Torr }\end{array}$ & Hygrom. & Ciel & Sky \\
\hline $5 \mathscr{A M}$ & $12,8-16.0$ & $27.10,0 \cdot 753.5$ & & A demi couvert. & Partially cloudy \\
\hline $1 P \mathcal{M}$ & $23,2 \cdot 29.0$ & $27.8,7 \cdot 750.6$ & 75 & toute la journée & all the day \\
\hline $9 P M$ & $17,4 \cdot 21.7$ & $27.7,9-748.7$ & & $\mathcal{N}$.L. d 10 hu3 du soir & New Moon 10:30 PM \\
\hline
\end{tabular}

Versailles. Les députés des trois ordres qui n'étaient pas arrivés fors de la présentation qui a eu lieu le 2 mai, ont
Versailles. The representatives of the three orders who did not arrive in time for the ceremony of May 2nd have the 
l'honneurd'être présentés et nommés au Roi par le marquis de Brézé, Grand Maître des cérémonies de France.

Le Bailli de la Brianne, Ambassadeut Extraordinaire de l'Ordre de Malte a, ce jour, en flabit de Cérémonie de l'Ordre, une audience particuliere du Roi, pendant laquelle if remet sa lettre de créance d Sa Majesté; cet ambassadeur, accompagné de beaucoup de baillis, commandeurs et chevaliers de l'Ordre qui lui font cortège, est conduit d l'audience de SaMajesté, et a celle de la Famille Royale, par le sieur de Tolozan, Introducteur des ambassadeurs. Le sieur de Séqueville, Secrétaire ordinaire du Roi pour la conduite des Ambassadeur, précède.

Leurs Majestés \& la Famille Royale signent le contrat de mariage du Comte de la Brisse d'Amilly, Officierau Régiment du Roi, avec Mademoiselle le Tonnelier de Breteuil, of celui du Comte Maurice de Caraman, Major en second des Carabiniers de Monsieur, avec Mademoiselle de la Garde.

Le soir, Leurs Majestés soupent a leur grand couvert; pendant le repas, la Musique du Roi exécute différents morceaux sous la conduite du sieurMartini, Surintendant de La Musique de Sa Majesté, en survivance. honour to be presented to the King by the Marquis de 'Brézé, the Great Master of Ceremonies of $\mathcal{F}$ rance.

The Bailiff de La Brianne, Ambassador-at-large of the Order of Malta, wearing the Order's official dress, is received this day in audience by the King, to remit fis credentials. This ambassador, surrounded in retinue by many bailiffs, commanders and chevaliers of the Otder, is led to the audience of His Majesty and of the Royal Family by Master de Tolozan, Introductor to the Ambassadors. Master de Séqueville, the King's Ordinary Secretary for Ambassadors, leads the party.

Their Majesties and the Royal Family sign the marriage contract between Count de la Brisse d'Amilly, Officer of the King's Regiment, with Mademoiselle Le Tonnelier de Breteuil, and that of Count Maurice de Caraman, first mate of Monsieur's /the Xing's brother] Carabineers, with Mademoiselle de la Garde.

In the evening, Their Majesties have supper in grand setting. During the meal, the King's chamber orchestra, conducted by old Master Martini, Superintendant of $\mathcal{H}$ is Majesty's Music, plays various pieces.

\section{Lundi 25 mai 1789}

$$
\text { Monday, May 25", } 1789
$$

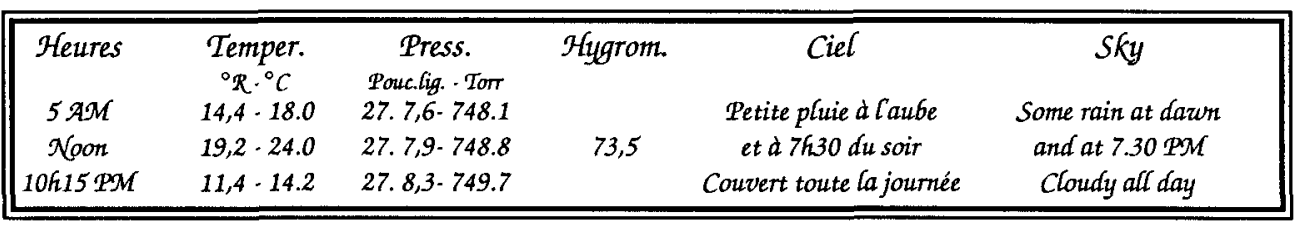

Versailles. Constatant que les débats ont été jusqu'à présent bruyants tumultueux, alors que la liberté suppose la discipline, le comte de Mirabeau propose la formation d'un règlement de police provisoire de l'assemblée des Communes afin "d'établirl'ordre of la liberté des débats, er recueillir les voix dans toutes leur intégrité" $\sigma$ de "prendre un mode de débattre $\nleftarrow$ de voter qui donne incontestablement le résultat de l'opinion de tous". Cette motion passe dl la pluralité de 436 voix contre 11.

La chambre de la Noblesse décide que le procès-verbal de ses séances sera imprimé chaque semaine.
Versailles. Observing that the discussions have up to now been tumultuous and noisy, whereas freedom requires discipline, Count de Mirabeau suggests the creation of a provisional internal regulation of the assembly of Commons, ith order "to establish order and freedom in the debates, and collect the votes in all their integrity', and to "choose a way to debate and to vote which will indisputably reflect everyone's opinion:. The motion passes by a majority of 436 to 11 .

The House of $\mathcal{N}$ obility decides that the minutes of its sessions will be printed each week. 
Poursuite des conférences entre les commissaires des trois ordres. Une proposition conciliatoire du Clergé est repoussée par les deux autres ordres. Elle portait que les pouvoirs de chaque député seraient vérifiés par la chambre de son ordre, puis confimés par les autres. Les cas litigieux devaient être examinés par des commissaires pris dans chacun des trois ordres.
The conferences between the commissioners of the three orders continue. $A$ concifiatory proposal of the Clergy is turned down by the two other orders. This proposal suggested that the proxies held by each representative would be checked by fis oum House, then confirmed by the other Houses, and that dubious cases would be examined by commissioners appointed by the thiree orders.

\section{Mardi 26 mai 1789}

$$
\text { Tuesday, May 26 } 1789
$$

\begin{tabular}{|c|c|c|c|c|c|}
\hline Heures & $\begin{array}{c}\text { Temper. } \\
{ }^{\circ} \mathrm{R} \cdot{ }^{\circ} \mathrm{C}\end{array}$ & $\begin{array}{c}\text { Press. } \\
\text { Pouc.ifg. } \\
\text { Torr }\end{array}$ & Hygrom. & Ciel & Sky \\
\hline $5 \not \mathscr{M M}$ & $11,6-14.5$ & $27.8,5 \cdot 750.1$ & & Pluie Laprès-midi et & Rain in the aftemoon \\
\hline $2.30 P \mathcal{M}$ & $14,9 \cdot 18.6$ & $27.8,9 \cdot 751.0$ & 81 & dans la soirée & and in the evening \\
\hline $9.15 \mathscr{P M}$ & $12,1-15.1$ & $27.9,2-751.7$ & & Couvert toute la joumée & Cloudy all day \\
\hline
\end{tabular}

Versailles. L'assemblée des communes décide dune très grande majorité que le règlement provisoire sur la police intérieure sera rédigé par le doyen ơ ses adjoints. Les com. missaires conciliateurs nommés par le Tiers font al'assemblée le rapport des conférences tenues le 23 et le 25 de ce mois. Les députés entendent avec satisfaction que Target, Mounier et Rabaud de Saint-Etienne ont réfuté "avec une excellente logique, des connaissances très approfondies" les objec. tions de la $\mathcal{N}$ (oblesse.

La chambre de la $\mathcal{N}$ (oblesse, après avoir entendu le rapport de ses commissaires, arrête da la pluralité de plus de 200 voix que, pour cette tenue des Etats Généraux les pouvoirs seront vérifiés séparément, 屯 qu'une nouvelle forme dobserver pour l'organisation des prochains Etats Généraux ne pourra être décidée que par l'assemblée constituée suivant les anciennes règles (c'est d̀ dire en votant par ordre, et avec droit de vote pour chaque ordre, donc sans espoir de changement). Par cet arrêté, la $\mathcal{N}$ oblesse rompt les négociations avec le Tiers.
Versailles. The assembly of Commons, to a very lange majority, decides that the provisional internal regulation will be written up by the dean and fis assistants. The conciliatory commissioners appointed by the Third Estate report to the assembly on the conferences field on the $23 r$ d and 25 th of this month. The representatives are satisfied to hear that Target, Mounier, and Rabaud de Saint-Etienne have refuted the objections of the $\mathcal{N}$ obility "with an excellent logic, and a very deep knowledge".

The House of the Nobility, after having heard the reports by its commissioners, votes by a majority of more than two hundred that, for this session of the Estates General, proxies will be checked separately, and that a new procedure, valid for the next session, can be decided only by an assembly formed according to the older rules. This means voting by order, with a veto for each order, effectively preventing any change to take place. By this decision, the $\mathcal{N}$ obility breaks the negotiations with the Third Estate.

\section{Mercredi 27 mai 1789}

$$
\text { Wednesday, May 27i, } 1789
$$

\begin{tabular}{|c|c|c|c|c|c|}
\hline $\begin{array}{l}\text { Heures } \\
5 \mathscr{A M}\end{array}$ & $\begin{array}{c}\text { Temper. } \\
{ }^{\circ} \mathrm{R} \cdot{ }^{\circ} \mathrm{C} \\
9,8 \cdot 12.2\end{array}$ & $\begin{array}{c}\text { Press. } \\
\text { Pouc.fig. - Tor } \\
27.9,3 \cdot 751.9\end{array}$ & Hygrom. & $\begin{array}{c}\text { Ciel } \\
\text { Pfuie toute la matitrée }\end{array}$ & $\begin{array}{c}\text { Sky } \\
\text { Rain in the morning }\end{array}$ \\
\hline $2.30 \not \mathcal{M M}$ & $14,5-18.1$ & $27.10,6-754.8$ & 80,5 & Quelques éclaircies dans & Some clearing in \\
\hline $9 P \mathcal{M}$ & $9,5 \cdot 11.9$ & $27.11,6 \cdot 757.1$ & & La soirée & the evening \\
\hline
\end{tabular}

Vetsailles. L'arrêté pris la veille par la Noblesse, et l'annonce qu'elle a communiqué au Cletgé afin de l'inviterd suivre son exemple, suscitent l'indignation dans la chambre
Versailles. The decision taken on the previous day by the Nobility, and the fact that it fias urged the Clergy to follow its example, infuriates the Commons. Count de Mirabeau 
des Communes. Le comte de Mirabeau propose que les Communes se toument vers le Clergé, qui a des prétentions d jouer le tôle de concifiateur, s'adressent dे lui "d'une manière qui ne laisse pas le plus petit prétexte du une évasion". En conséquence, les Communes envoient au Clergé une députation solennelle chargée de transmettre le message suivant: "Les députés des communes adjurent, au nom du Dieu de paix au nom de l'intérêt national, $\mathcal{M M}$. du Clergé de se réunir d̀ eux daths la salle de l'assemblée générale, pour aviser aux moyens d'opérer l'union to la concorde, si nécessaires en ce moment au salut de la chose publique".

Plusieurs curés proposent de déférer inmédiatement d cette invitation. Mais les évêques parviennent d faire retomber l'enthousiasme, o deux prélats vont annoncer au Tiers-Etats que le Clergé s est occupé avec zèle d'une matière d'un sigrand intérêt; mais que la séance s'étant prolongée audeld de trois fieures, ils se sont séparés of ont remis la délibération au lendemain.

\section{Juin - Octobre 1789}

Laguerre des ordres qui se déroule d Versailles continuera de fixer l'attention de la France of de l'Europe.

Après plusieurs péripéties, le Tiers-Etat entreprendra seul, le 12 juin, la vérification des pouvoirs de tous les députés. Après avoir été rejoint par plusieurs membres du bas clergé, if se proclamera le 17 juin, "Assemblée Nationale" (c'est d dire les seuls représentants légitimes de la Nation, habilités d faire de nouvelle lois d donner une constitution au royaume).

Le 20 juin, la salle des Menus Plaisits ayant été fermée d'autorité, les députés se réunissent dans la salle du geu de Paume, font le serment solennel de ne pas se séparer avant d'avoir donné une constitution d la F Fance.

Le 23 juin, au cours d'une "séance royale", Le Roi déclare nuls les actes du Tiers-Etat, et il présente son programme de réformes. Mais le refus opposé par le Tiers aux ordres du Roi lui enjoignant de quitter la salle, montre qu'un nouveau pouvoir est né, face au pouvoirjusque ld unique du monarque. suggests that the Commons turn torwards the Clergy, which claims to play a concifiatory role, and speak to it win a manner that leaves absolutely no room for ambiguity". Consequently, the Commons send a solemn delegation in charge of remitting to the Clergy the following message: "the representatives of the Commons, in the name of the God of peace, and in the name of the nation's interest, beg the members of the Clergy to join them in the room of the general assembly, to study the ways and means to reach union and concord, now so necessary for the salvation of the public interest.

Several priests propose to immediately accept this invitation. But the bisfops succeed in cooling heads down, and two prelates announce to the Third Estate that the Clergy frad zealously examined such an interesting matter; but since the session lasted until after three, they had to adjourn and postpone their deliberation until the following day.

\section{June - October 1789}

In the following weeks, the war between the orders taking place in Versailles will continue to attract the attention in $\mathcal{F}$ rance and throughout Europe.

After several turns, the Third Estate will undertake to check alone the proxies of all the representatives. After having been joined by several members of the Lower clergy, it will proclaim itself "National Assembly" on June 17th, meaning that it comprises the only legitimate representatives of the nation, empowered to decide new laws, and to give a constitution to the kingdom.

On Iune 20th, the Room of the Little Pleasures having been closed by order of the King, the representatives gather in the Room of the Palm Game, and take the solemn oath not to leave without having given France a constitution.

On June 23rd, during a "royal session", the King declares the acts of the Third Estates void, and presents his own program of reforms. But the refusal of the Third Estate to obey the King's orders to leave the room shows that a new power is 6orn, confronting the until now only power of the monarch. 
Les 24 et 25 juin, la majorité du Clergé ó une importante minorité de la $\mathcal{N}$ (oblesse rejoignent l'Assemblée Nationale. Dés lors, le Roi est obligé de céder, đo il demande lui-même d la majorité de la $\mathcal{X}$ oblesse de rejoindre les autres députés (27) juin).

\section{La révolution est faite.}

C'est le refus de la Cour de reconnaître la nouvelle situation, of les tentatives maladroites poury mettre un terme, qui provoqueront l'insurrection de juillet d Paris dont l'épisode saillant, la prise de la Bastille, n'est que la démonstration symbolique de la fin de l'absolutisme royal.

C'est encore d Versailles que l'Assemblée Nationale proclamera l'abolition du régime féodal ớ des privilèges (nuit du 4 août), \& la Déclaration des droits de ('homme et du citoyen (20-26 août). Pourtant la présence d Versailles, ville née du caprice d'un souverain tout-puissant, des organes de décision n'est plus qu'un anacfronisme.

Le 5 octobre, les parisiens, sur ['initiative des femmes du peuple, viennent d Versailles réclamer du pain. Ils ramènent Le lendemain dans la capitale la famille royale ("Le boulanger, La boulangère, Le petit mitron").

L'Assemblée Nationale, qui n'a vraiment plus rien d faire dans ce décor d'un autre temps, témoignage de ce que pouvait la volonté d'un monarque absolu, suivra de peu le Roi, et ita s'établir d Paris le 19 octobre.

Le rôle de Vetsailles est terminé.

Une page de l'histoire est définitivement toumée.
On gune 24th and 25th, the majority of the Clergy and a significant fraction of the Nobility join the National Assembly. The King is then forced to yield, and, on June 27th, he asks the majority of the $\mathcal{N}$ obility to join the other representatives.

The revolution is over.

It is only because the Court refuses to acknowledge the new situation and tries unsuccessfully to stop it, that riots will take place in Paris in $g_{u l y}$. The most famous episode, the taking of the Bastille prison, only symbolically demons trates that royal absolutism has come to an end.

Again in Versailles, the National Assembly will proclaim the abolition of the feudal system and of all privileges (on the eve of August 4 th), and the Declaration of the Rights of Man and of the Citizens (August 20th to 26th). The presence of the deciding bodies in Versailles, a city created by the whim of an all-powerful sovereign, is not anachronistic any more.

On October 1st, Parisians, pushed by the women, come to Versailles to ask for bread, and on the following day, they take the Royal Family ("the baker, the Gaker's wife, and the Cittle baker's boy") to the capital.

The National Assembly, faving nothing more to do in this scenery of ancient times testifying of the will of an absolute monarch, soon follows the King and settles in Paris on October 19 th.

The role of Versailles is over.

$A$ chapter of fistory is closed forever. 